\title{
STANDARD LUMBAR DISCECTOMY VERSUS MICRODISCECTOMY - DIFFERENCES IN CLINICAL OUTCOME AND REOPERATION RATE
}

\author{
Vojin Kovačević ${ }^{1,2}$, Nemanja Jovanović ${ }^{1,2}$, Marina Miletić-Kovačević ${ }^{1}$, Radivoje Nikolić ${ }^{1,2}$, \\ Miodrag Peulić1,2, Krešimir Rotim ${ }^{3,4}$, Tomislav Sajko ${ }^{3,4}$ and Lukas Rasulićc ${ }^{5,6}$
}

${ }^{1}$ Faculty of Medical Sciences, University of Kragujevac; ${ }^{2}$ Center for Neurosurgery, Kragujevac Clinical Center, Kragujevac, Serbia; ${ }^{3}$ University of Applied Health Sciences, Zagreb, Croatia; ${ }^{4} \mathrm{Clinical}$ Department of Neurosurgery, Sestre milosrdnice University Hospital, Zagreb, Croatia; ${ }^{5}$ School of Medicine, University of Belgrade;

${ }^{6}$ Clinical Department of Neurosurgery, Clinical Center of Serbia, Belgrade, Serbia

SUMMARY - Microdiscectomy (MD) is accepted nowadays as the operative method of choice for lumbar disc herniation, but it is not rare for neurosurgeons to opt for standard discectomy (SD), which does not entail the use of operating microscope. In our study, differences in disc herniation recurrence and clinical outcome of surgical treatment of lumbar disc herniation with and without the use of operating microscope were assessed. Our study included 167 patients undergoing lumbar disc surgery during a three-year period ( $\mathrm{SD}, \mathrm{n}=111$ and $\mathrm{MD}, \mathrm{n}=56$ ). Clinical outcome assessments were recorded by patients via questionnaire forms filled out by patients at three time points. Operation duration, length of hospital stay and revision surgeries were also recorded. According to study results, after one-year follow up there was no statistically significant difference between the SD and MD groups in functional outcome. However, we recorded a statistically significant difference in leg pain reduction in favor of the $\mathrm{MD}$ group. According to the frequency of reoperations with the mean follow up period of 33.4 months, there was a statistically significant difference in favor of the MD group (SD $6.3 \%$ vs. MD 3.2\%). There appears to be no particular advantage of either technique in terms of functional outcome since both result in good overall outcome. However, we choose MD over SD because it includes significantly lower recurrent disc herniation rate and higher reduction of leg pain.

Key words: Microdiscectomy; Standard discectomy; Clinical outcome; Reoperation

\section{Introduction}

Elective lumbar discectomy is regarded a good treatment option for lumbar disc herniation and one of the most common neurosurgical procedures. Discectomy is considered the gold standard in the treatment of lumbar disc herniation patients if sciatica or neurological deficits occur and still persist after a course of conservative therapy ${ }^{1,2}$. In 1934, Mixter and Barr were

Correspondence to: Prof. Lukas Rasulic, MD, PhD, Clinical Department of Neurosurgery, Clinical Center of Serbia, Dr Koste Todorovića 4, 11000 Belgrade, Serbia

E-mail: lukas.rasulic@gmail.com

Received September 1, 2016, accepted June 30, 2017 the first to recognize herniated disc as a common cause of neural compression in the lumbar spinal canal and advocated surgical approach to the problem ${ }^{3}$. Surgical approach, commonly known as standard discectomy, is still employed today, accompanied by a number of technical modifications implemented over years, and includes partial hemilaminectomy and partial discectomy for herniated disc removal. A new era in the operative management of lumbar disc herniation began in the year 1977 with the use of operating microscope for surgical removal of herniated disc material ${ }^{4,5}$. Soon after the introduction of the above mentioned innovation, according to the first results, it was pointed out that microdiscectomy was just as efficient as standard 
discectomy, having certain advantages over the latter ${ }^{6}$. Compared with the standard open discectomy, microdiscectomy enabled the use of smaller incisions of the skin and fascia and facilitated a less traumatic surgical procedure, thereby reducing postoperative pain and hospital stay.

Although microdiscectomy is accepted nowadays as the method of choice for the presenting pathology, it is not rare for neurosurgeons to opt for standard discectomy, which does not entail the use of operating microscope. Over the last two decades, several kinds of operative techniques have been generated in the treatment of lumbar disc herniation patients (chemonucleolysis, laser discectomy and endoscopic-assisted techniques), but they have not become widely accepted into clinical practice due to having a limited range of indications and often unsatisfactory clinical results ${ }^{7-9}$. The newer minimally invasive methods (microendoscopic or tubular discectomy), which appear to be generally accepted nowadays, have been proven to be a satisfactory alternative to microdiscectomy. The major advantages of endoscopic discectomy are reported to include significantly less muscle damage ${ }^{10}$ and less peridural scar tissue formation ${ }^{11}$. However, there were no statistically significant differences in the final clinical treatment outcome ${ }^{12}$.

Several retrospective ${ }^{13-15}$ and prospective ${ }^{16,17}$ randomized studies have been published so far, comparing the relative merits of microdiscectomy and standard discectomy, which imposes a general conclusion that there is no clinically relevant difference in the clinical treatment outcome even after continuous long-term monitoring of patients.

It is our belief that a drawback of prospective randomized studies is the fact that they are highly influencing the choice of surgical procedure performed by the individual surgeon because if the surgeon is not familiar with his/her own chosen method, its application can affect the final clinical treatment outcome. In addition, most of the studies are dedicated to the surgical aspects in the treatment of patients, including possible complications, surgery duration and hospital stay. Although pain assessment method is covered in numerous studies, there are quite a few studies that include patient self-rated outcome scale, which turns out to be essential in the clinical outcome assessment. Unlike most other studies, we included the problem of recurrent disc herniation that required reoperation.
Our study presents an attempt to make a multidimensional comparison between the course and outcome of surgical treatment of lumbar disc herniation with and without the use of operating microscope.

\section{Patients and Methods}

Our study was designed as a prospective non-randomized study and it included patients undergoing lumbar disc surgery during the three-year period at the Center for Neurosurgery, Kragujevac Clinical Center in Kragujevac, Republic of Serbia. Clinical outcome assessments were recorded by the patients via questionnaire forms filled out by the patients preoperatively, three months after surgery and properly conducted physical therapy program, and also one year after surgery. The questionnaires contained the following parameters: Visual Analog Scale (VAS, 0-10) used as a tool in quantifying patient experience of back and leg pain intensity and Oswestry Disability Index (ODI, 0-100\%disability) used for assessment of disability and functional recovery in patient daily activities. The ODI is considered the 'gold standard' of low back functional outcome tools ${ }^{18}$. Operation duration, length of hospital stay and revision surgeries were also recorded.

The mean follow-up in terms of potential reoperation and other surgical complications in the postoperative period was 33.4 months.

The criteria for inclusion into the study were defined as: single level lumbar disc herniation; monoradicular symptoms with predominant sciatica compared to less severe lower back pain; conservative treatment failure or intolerable sciatica, or rapidly progressive neurological deficits (including motor deficits, bladder dysfunction, partial and complete cauda equina syndrome).

Exclusion criteria were defined as a history of previous lumbar back surgery; signs of spinal instability or other spinal abnormalities; excessive obesity; body mass index above $35^{19}$; and history of psychiatric or addiction and mental disorders.

Procedures were performed under general anesthesia and patients were placed in the genupectoral position. The affected interlaminar space was localized by lateral $\mathrm{x}$-ray fluoroscopy just before and with confirmation during surgery. Microdiscectomy was performed after a horizontal skin incision of approximately $4-5 \mathrm{~cm}$ in length above the lumbar spinal seg- 
ments and incision of lumbodorsal fascia and subperiostal preparation to the interlaminar space. Using the operating microscope (Carl Zeiss Co., OPMI Vario/NC33, Oberkochen, Germany), the following aspects of the surgery were performed: partial hemilaminectomy of the superior and inferior lamina and partial flavectomy. After these aspects had been performed, the herniated disc was removed. In addition, all patients were mobilized during the first 24 hours after surgery.

The protocol of the present study was approved by the institutional ethics committee.

Data are presented as mean \pm standard deviation (SD) or median (range). For comparison of the two treatment modalities, the independent samples t-test was used for normally distributed data and the MannWhitney test for skewed data. The paired samples $t$ test was used to test statistical difference between two time points within each procedure. The $\chi^{2}$-test was used to analyze the association between surgical group and reoperation rate. Statistical significance was accepted at the $\mathrm{p} \leq 0.05$ level. Statistical data analyses were done using SPSS Statistics 22.

\section{Results}

During the study period, 223 patients diagnosed with lumbar disc herniation underwent surgery by four experienced neurosurgeons. The study admission criteria were satisfied by 167 patients and at the same time they were available when requested to complete the questionnaires. Depending on the surgeon's preference, 111 patients underwent surgery by using the method of standard discectomy, that is, without using operative microscope, whereas 56 patients underwent surgery by the method of microdiscectomy. The standard discectomy group had 57 men and 54 women undergoing surgery, whereas the microdiscectomy group included 34 men and 22 women. The mean age of patients in the standard discectomy group (SD) and microdiscectomy group (MD) was 44.9 (range: $17-75$ ) years and 44.8 (range: 19-67) years, respectively. The most common level of disc herniation was at the level of $\mathrm{L} 5 / \mathrm{S} 1$ lumbar vertebrae in both groups $(\mathrm{SD}, \mathrm{n}=61$ and $\mathrm{MD}, \mathrm{n}=28$ ), and then at the level of L4/L5 (SD, $\mathrm{n}=33$ and $\mathrm{MD}, \mathrm{n}=17$ ).

There were no statistically significant group differences in the operation duration or the length of hospital stay. In both groups, surgery was usually completed during the first hour from the beginning of operation, which was observed in $74.3 \%$ of SD cases and $68.7 \%$ of MD cases. The mean duration of hospital stay was $5.6 \pm 2.8$ (range: $3-9$ ) days in the SD group and 6.7 \pm 3.1 (range: 4-11) days in the MD group.

The mean preoperative ODI score in the SD group was $58.34 \pm 21.32$ (range: $23-94$ ) and mean VAS leg

Table 1. Initial parameters and operation details

\begin{tabular}{|c|c|c|c|}
\hline Variable & $\begin{array}{l}\text { Standard discectomy } \\
\text { group }\end{array}$ & $\begin{array}{l}\text { Microdiscectomy } \\
\text { group }\end{array}$ & $\mathrm{p}$ value \\
\hline Number of patients & 111 & 56 & \\
\hline $\begin{array}{l}\text { Gender } \\
\text { - male } \\
\text { - female }\end{array}$ & $\begin{array}{l}57 \\
54\end{array}$ & $\begin{array}{l}34 \\
22 \\
\end{array}$ & \\
\hline Patient age (years) & $44.9(17-75)$ & $44.8(19-67)$ & $\mathrm{p}=0.95$ \\
\hline $\begin{array}{l}\text { Operation duration (h) } \\
<1 \mathrm{~h} \\
>1 \mathrm{~h}\end{array}$ & $\begin{array}{l}74.3 \% \\
25.7 \%\end{array}$ & $\begin{array}{l}68.7 \% \\
31.3 \%\end{array}$ & $\mathrm{p}=0.43$ \\
\hline Hospital stay (days) & $5.6 \pm 2.8$ & $6.7 \pm 3.1$ & $p=0.87$ \\
\hline Preoperative VAS leg pain & $\begin{array}{l}7.7 \pm 1.9 \\
\text { (range: } 2.5-9.2 \text { ) }\end{array}$ & $\begin{array}{l}8.2 \pm 2.1 \\
\text { (range: } 2.3-9.6 \text { ) }\end{array}$ & $p=0.26$ \\
\hline Preoperative VAS back pain & $\begin{array}{l}4.7 \pm 2.2 \\
\text { (range: } 1.8-6.5 \text { ) }\end{array}$ & $\begin{array}{l}4.2 \pm 1.9 \\
\text { (range: } 1.5-6.2 \text { ) }\end{array}$ & $\mathrm{p}=0.33$ \\
\hline Preoperative ODI (\%) & $58.34 \pm 21.32$ & $55.1 \pm 19.13$ & $\mathrm{p}=0.7$ \\
\hline
\end{tabular}

VAS = Visual Analog Scale; ODI = Oswestry Disability Index 
Table 2. Clinical outcome 3 months after surgery

\begin{tabular}{|l|l|l|l|}
\hline Variable & $\begin{array}{l}\text { Standard discectomy } \\
\text { group }\end{array}$ & $\begin{array}{l}\text { Microdiscectomy } \\
\text { group }\end{array}$ & $\mathrm{p}$ value \\
\hline $\begin{array}{l}\text { 3-month postoperative } \\
\text { VAS leg pain }\end{array}$ & $\begin{array}{l}3.0 \pm 2.5 \\
\text { (range: } 0.5-7.5)\end{array}$ & $\begin{array}{l}2.8 \pm 2.3 \\
\text { (range: } 0-7)\end{array}$ & $\mathrm{p}=0.69$ \\
\hline $\begin{array}{l}\text { 3-month postoperative } \\
\text { VAS back pain }\end{array}$ & $\begin{array}{l}2.1 \pm 2.2 \\
\text { (range: } 1-5.2)\end{array}$ & $\begin{array}{l}1.9 \pm 2.0 \\
\text { (range: } 0-6.1)\end{array}$ & $\mathrm{p}=0.89$ \\
\hline $\begin{array}{l}\text { 3-month postoperative ODI } \\
(\%)\end{array}$ & $\begin{array}{l}25.67 \pm 18.43 \\
\text { (range: } 4-63)\end{array}$ & $\begin{array}{l}22.4 \pm 16.14 \\
\text { (range: } 0-43)\end{array}$ & $\mathrm{p}=0.7$ \\
\hline $\begin{array}{l}\text { VAS leg pain reduction } \\
\text { after 3 months }\end{array}$ & 4.7 & 5.4 & $\mathrm{p}=0.08$ \\
\hline $\begin{array}{l}\text { VAS back pain reduction } \\
\text { after 3 months }\end{array}$ & 2.6 & 2.3 & $\mathrm{p}=0.67$ \\
\hline $\begin{array}{l}\text { Reduction in ODI } \\
\text { after 3 months }\end{array}$ & 32.67 & 32.7 & $\mathrm{p}=0.93$ \\
\hline
\end{tabular}

VAS = Visual Analog Scale; ODI = Oswestry Disability Index

pain level was $7.7 \pm 1.9$ (range: $2.5-9.2$ ). The mean preoperative ODI score in the MD group was $55.1 \pm 19.13$ (range: 26-87) and mean VAS leg pain level was 8.2 \pm 2.1 (range: $2.3-9.6$ ). Patients in the SD group had a baseline mean low back pain (LBP) score of $4.7 \pm 2.2$ (range: 1.8-6.5), whereas patients in the MD group had a mean LBP score of 4.2 \pm 1.9 (range: 1.5-6.2). There was no statistically significant difference between the two groups according to these initial parameters (Table 1).

While completing the questionnaires for the second time at 3 months postoperatively, significant reduction was noted in the perceived pain score for leg pain and for LBP in both study groups. The mean VAS for leg pain in the SD group was 3.0 \pm 2.5 (range: 0.57.5 ), compared to $2.8 \pm 2.3$ (range: $0-7$ ) in the $\mathrm{MD}$ group. The mean VAS for LBP in the SD group was $2.1 \pm 2.2$ (range: $1-5.2$ ), compared to $1.9 \pm 2.0(0-6.1)$ in the MD group. Also, a significant decrease in ODI values was observed: $25.67 \pm 18.43$ (range: $4-63$ ) in the SD group and $22.4 \pm 16.14$ (range: $0-43$ ) in the MD group. There was no statistically significant difference between the two groups in the monitored parameters after three months of surgery. There was no statistically significant difference in the reduction of ODI and VAS values for leg and back pain at three months either (Table 2).

At 12-month follow-up after operative treatment, the patients were requested to complete the questionnaires once again. Both groups showed a clinically im- portant trend towards a decrease in the VAS of leg pain and ODI scores, whereas LBP values determined using the VAS scale demonstrated a minimum decrease compared to the previous examination. The $\mathrm{SD}$ patients displayed the mean leg pain level of $2.3 \pm$ 2.5 (range: $0-7.5$ ), median back pain of $2 \pm 1.9$ (range: $0-5.5$ ) and ODI of $19.13 \pm 15.69$ (range: $0-60$ ). The $\mathrm{MD}$ patients had the mean leg pain of $1.9 \pm 2.5$ (range: $0-7$ ), median back pain of $1.60 \pm 2.0$ (range: $0-6$ ), and ODI of $14.65 \pm 13.2$ (range: $0-32$ ). At one-year follow-up, improvement of preoperative leg pain according to VAS was $5.4(\mathrm{p}<0.001)$ in SD patients and $6.3(\mathrm{p}<0.001)$ in MD patients.

Significant reduction in LBP intensity was noted as well. The corresponding values for LBP reduction were 2.7 in the $\mathrm{SD}$ group and 2.6 in the MD group. The preoperative mean ODI values after one year decreased by 39.21 in the SD group and by 40.45 in the MD group ( $\mathrm{p}<0.001$ both), yielding a statistically significant improvement in both groups. At one-year follow-up, there was no statistically significant difference between the SD and MD groups according to the reduction in VAS score for back pain or reduction in ODI values. However, we recorded significant difference in the leg pain reduction by VAS ( $\mathrm{p}=0.038)$ in favor of the MD group (Table 3).

Of the 167 patients in the database with the mean follow-up of 33.4 months, nine (5.4\%) patients underwent reoperation. In the SD group, seven (6.3\%) patients underwent reoperation, whereas five (4.5\%) pa- 
Table 3. Clinical outcome 12 months after surgery and reoperation rate

\begin{tabular}{|l|l|l|l|}
\hline Variable & $\begin{array}{l}\text { Standard discectomy } \\
\text { group }\end{array}$ & $\begin{array}{l}\text { Microdiscectomy } \\
\text { group }\end{array}$ & $\mathrm{p}$ value \\
\hline $\begin{array}{l}\text { 12-month postoperative } \\
\text { VAS leg pain }\end{array}$ & $\begin{array}{l}2.3 \pm 2.5 \\
\text { (range: 0-7.5) }\end{array}$ & $\begin{array}{l}1.9 \pm 2.5 \\
\text { (range: 0-7) }\end{array}$ & $\mathrm{p}=0.37$ \\
\hline $\begin{array}{l}\text { 12-month postoperative } \\
\text { VAS back pain } \\
\text { (median) }\end{array}$ & $\begin{array}{l}2 \pm 1.9 \\
\text { (range: } 0-5.5)\end{array}$ & $\begin{array}{l}1.60 \pm 2 \\
\text { (range: 0-6) }\end{array}$ & $\mathrm{p}=0.23$ \\
\hline $\begin{array}{l}\text { 12-month postoperative ODI } \\
\text { (\%) }\end{array}$ & $\begin{array}{l}19.13 \pm 15.69 \\
\text { (range: 0-60) }\end{array}$ & $\begin{array}{l}14.65 \pm 13.2 \\
\text { (range: } 0-32)\end{array}$ & $\mathrm{p}=0.19$ \\
\hline $\begin{array}{l}\text { VAS leg pain reduction } \\
\text { after 12 months }\end{array}$ & 5.4 & 6.3 & $\mathrm{p}=\mathbf{0 . 0 3 8}$ \\
\hline $\begin{array}{l}\text { VAS back pain reduction } \\
\text { after 12 months }\end{array}$ & 2.7 & 2.6 & $\mathrm{p}=0.75$ \\
\hline $\begin{array}{l}\text { Reduction in ODI } \\
\text { after } 12 \text { months }\end{array}$ & $\begin{array}{l}39.21 \\
(\mathrm{p}<0.001)\end{array}$ & $\begin{array}{l}40.45 \\
(\mathrm{p}<0.001)\end{array}$ & $\mathrm{p}=0.86$ \\
\hline Reoperation rate $(\%)$ & 5.4 & 3.2 & $\mathrm{p}=\mathbf{0 . 0 0 0 1}$ \\
\hline
\end{tabular}

VAS $=$ Visual Analog Scale ODI $=$ Oswestry Disability Index

tients underwent reoperation because of recurrent disc herniation. Due to postoperative recurrent radicular pain, two patients received the treatment of fibrous adhesions of spinal nerve roots caused by scar tissue formation. Of the 56 patients in the MD group, two (3.2\%) patients underwent reoperation and one (1.78\%) patient underwent reoperation because of recurrent disc herniation. According to the frequency of reoperations, there was a statistically significant difference in favor of the MD group ( $\mathrm{p}=0.0001)$. The SD patients underwent reoperation at 6-28 (mean, 16.5) months after their first surgery.

\section{Discussion}

The present study sought to investigate differences in the functional outcome after lumbar disc excision with and without the use of microscope, and also to detect whether there were significant differences in terms of the pain syndrome reduction. If each group is assessed separately, both groups displayed significant improvement in terms of leg and low back pain intensity scores, showing good recovery according to the ODI. The only statistically significant difference noted between the two groups was reduction in the leg pain intensity score. Although no significant difference was noted at 3 months post-surgery, there was a statistically significant reduction in leg pain intensity at 12 months in the MD group (pain reduced by 6.3 points) compared to the SD group (pain reduced by 5.4 points). The verified difference could be attributed to the lower preoperative leg pain score in the SD group, which could be caused by better patient selection for operative treatment in the MD group.

Although we had expected better functional outcomes after surgical treatment in the MD group because they had the advantage of less tissue trauma and better visualization, no statistically significant differences were detected between the two groups in outcomes based on the results obtained by the ODI and VAS. Our starting hypothesis was not verified in the works of other authors either, who used various questionnaires for treatment outcome assessment ${ }^{14,16,24,25}$. Most of the above mentioned studies share the same view related to the significant reduction in leg and low back pain intensity in both groups, completed with excellent functional recovery, but the overall results are not statistically and clinically significant. In addition, some segments of the studies show the authors' preference for one of the treatment modalities. However, their overall results are generally heterogeneous.

The main reason why our study differs from the majority of other studies is the follow-up of lumbar disc reherniation rate and the need for reoperation. The abovementioned studies do not give their views on recurrent lumbar disc herniation. Our study showed 
that after microdiscectomy, there was a statistically less chance of reoperative treatment because of recurrent lumbar disc herniation or excessive fibrous traction of the dural sac and spinal roots. We attribute this result to better visualization of the neural structure and pathologic substrate, and their mutual relations. According to a few available studies on recurrent lumbar disc herniation, the reoperation rate is $6 \%-24 \%$ depending on the length of follow-up ${ }^{20-22}$. Studies having similar length of follow-up just like ours are reported to have the reoperation rate of approximately $10 \%{ }^{23}$, which is a considerably higher rate compared to our study. However, it is not the difference related to the reoperation rate that proves the higher level of efficiency in lumbar disc herniation treatment (demonstrated by our own results), but the reasons for claiming this should be found in setting different indications for reoperation.

In the present study, the use of microscope did not lengthen the duration of the operation, although a higher percentage of the operation cases in the SD group lasted for less than one hour. The operating time varies in other studies depending on the use of microscope. Our results are in agreement with the findings of some earlier studies ${ }^{26}$, some of which even report a shorter operation time when using the standard discectomy technique ${ }^{16,17,24}$. However, there are only a few authors who came to the following conclusion and report a shorter operation time when using the microscope $^{14}$. The operating time is an important factor to consider, especially the aspect of blood loss and intraoperative risk factors for surgical site infections. According to the findings of some studies, one of the benefits of microdiscectomy is a significantly decreased perioperative blood $\operatorname{loss}^{26-28}$. In terms of surgical data, considering the fact that the increased visualization allowed for smaller incisions of the skin and fascia, less tissue trauma and more efficient hemostasis are expected. However, bearing in mind that blood loss reported for standard discectomy does not affect the hemodynamic stability of the patient, the aforementioned surgical data cannot be taken as an essential factor for the choice of one of the surgical methods given. In addition, blood loss is directly proportionate to the length of operation duration, which is frequently dependent on the individual surgeon's skills per se, and not so much on the operating method preferred.

Our study concurs with the recently published results $^{16,25,26}$, which demonstrated that both standard discectomy and microdiscectomy were appropriate techniques with no difference in outcomes. However, studies concerned with patient earlier return to work/ normal activities are reported to choose microdiscectomy over standard discectomy ${ }^{24,28}$. These results were explained by the correspondingly reduced tissue trauma during microsurgery. However, the results given should not be fully taken into consideration because they are strongly influenced by differences in the worker compensation policies in different countries worldwide.

As regards the length of hospital stay, there was no clinically relevant difference between the two groups in our study. There are some studies favoring microdiscectomy ${ }^{16,27,28}$, but also there are other studies supporting the results obtained in our study ${ }^{26}$. However, this variable, too, is often dependent on the factors other than the medical ones, such as healthcare policies and insurance systems in a particular country.

When making comparison between our study and a number of similar studies in this respect, some studies are reported to have the following drawbacks: retrospective character ${ }^{28}$, and the fact that there is only one surgeon and patients randomized to treatment by using one of the aforementioned methods ${ }^{13,16}$. If the validity of our study is subject to discussion, it is our belief that its main advantages were related to the fact that the surgeon was enabled to implement a familiar technique and relatively uniform indications for surgery. In addition, in our study, patients were not randomized to treatment by the use of specific modality, but it was the surgeon who made final choice in the way that best served the patients' interests, and the choice itself was related to the adequate treatment modality, depending on the pathology-based substrate. Apart from the patient inclusion criteria for the study, the approximate mean initial VAS and ODI values provide similar indications for surgery. The similarity of frequency of disc herniation level, gender distribution and mean age in both groups additionally demonstrate the level of compatibility between the two patient groups. Finally, although the two group sizes were different, the MD group size (56 patients) was still large enough to give the study sufficient power to reach appropriate conclusions.

We have come to a conclusion that in terms of $\mathrm{pa}^{-}$ tient-rated outcomes, there appears to be no particular advantage of either technique for the operative treat- 
ment since they both result in good overall outcome. In addition, there was no significant difference in the overall functional outcome after standard discectomy and microdiscectomy procedures. Bearing in mind the results obtained, along with a constant tendency in spine surgery towards developing minimally invasive techniques, an important concern has been raised regarding the justification of financing a plethora of the above mentioned tools for minimally invasive spinal surgery. Good overall long-term functional outcome in both groups imposes a conclusion that the surgeon should make decision to use a specific operative technique relating to whether he/she is adept in his/her own chosen method. However, we choose microdiscectomy over standard discectomy because it includes a significantly lower recurrent disc herniation rate and higher reduction of leg pain, as observed in the present study. In addition, one of the most obvious advantages of microdiscectomy is its superiority in teaching younger colleagues, for it provides a brief overview of insights into the neuroanatomy and pathologic substrate, which is not always possible to achieve when it comes to standard discectomy.

\section{References}

1. Gibson JN, Waddell AG. Surgical interventions for lumbar disc prolapse: updated Cochrane Review. Spine. 2007;32-16:173547. http://dx.doi.org/10.1097/BRS.0b013e3180bc2431

2. Peul WC, van Houwelingen HC, van den Hout WB, Brand R, Eekhof JA, Tans JT, Thomeer RT, Koes BW. Surgery versus prolonged conservative treatment for sciatica. N Engl J Med. 2007;356:2245-56. http://dx.doi.org/10.1056/NEJMoa064039

3. Mixter WJ, Barr JS. Rupture of the intervertebral disc with involvement of the spinal canal. N Engl J Med.1934;211:210-25. http://dx.doi.org/10.1056/NEJM193408022110506

4. Caspar W. A new surgical procedure for lumbar disc herniation causing less tissue damage through a microsurgical approach. Adv Neurosurg. 1977;4:74-80. http://dx.doi.org/10.1007/9783-642-66578-3_15

5. Yasargil MG. Microsurgical operation for herniated disc. Adv Neurosurg. 1977;4:81. http://dx.doi.org/ 10.1007/978-3-64266578-3_16

6. Williams RW. Microlumbar discectomy: a conservative surgical approach to the virgin herniated lumbar disc. Spine. 1978;32:175-82.

7. Day AL, Savage DF, Friedman WA, Sypert GW. Chemonucleolysis versus open discectomy: the case against chymopapain. Clin Neurosurg. 1986;33:385-96.
8. Schenk B, Brouwer PA, Peul WC, van Buchem MA. Percutaneous laser disk decompression: a review of the literature. AJNR Am J Neuroradiol. 2006;27:232-5.

9. Schreiber A, Suezawa Y. Transdiscoscopic percutaneous nucleotomy in disk herniation. Orthop Rev. 1986;15:35-8.

10. Shin DA, Kim KN, Shin HC, Yoon DH. The efficacy of microendoscopic discectomy in reducing iatrogenic muscle injury. J Neurosurg Spine. 2008;8-1:39-43. http://dx.doi.org/10.3171/ SPI-08/01/039

11. Gempt J, Jonek M, Ringel F, Preuß A, Wolf P, Ryang Y. Longterm follow-up of standard microdiscectomy versus minimal access surgery for lumbar disc herniations. Acta Neurochir. 2013; 155:2333-8. http://dx.doi.org/10.1007/s00701-013-1901-z

12. Arts MP, Brand R, van den Akker ME, Koes BW, Bartels RH, Tan WF, Peul WC. Tubular discectomy versus conventional microdiscectomy for the treatment of lumbar disc herniation: two-year results of a double-blind randomised controlled trial. Neurosurgery. 2011;69:135-44. http://dx.doi.org/10.1227/ NEU.0b013e318214a98c

13. Andrew DW, Lavyne MH. Retrospective analysis of microsurgical and standard lumbar discectomy. Spine. 1990;15:329-35.

14. Barrios C, Ahmed M, Arrotegui J, Bjornsson A, Gillstrom P. Microsurgery versus standard removal of the herniated lumbar disc. A3-year comparison in 150 cases. Acta Orthop Scand. 1990;61:399-403.

15. Sachdev VP. Lumbar discectomy under the operating microscope. Mt Sinai J Med. 1991;58:147-9.

16. Katayama Y, Matsuyama Y, Yoshihara H, Sakai Y, Nakamura $\mathrm{H}$, Nakashima S, Ito Z, Ishiguro N. Comparison of surgical outcomes between macrodiscectomy and microdiscectomy for lumbar disc herniation: a prospective randomized study with surgery performed by the same spine surgeon. J Spinal Disord Tech. 2006;19:344-7. http://dx.doi.org/10.1097/01. bsd.0000211201.93125.1c

17. Henriksen L, Schmidt K, Eskesen V, Jantzen E. A controlled study of microsurgical versus standard lumbar discectomy. Br J Neurosurg. 1996;10:289-93.

18. Fairbank JC, Pynsent PB. The Oswestry Disability Index. Spine. 2000;25-22:2940-52.

19. Meredith DS, Huang RC, Nguyen J, Lyman S. Obesity increases the risk of recurrent herniated nucleus pulposus after lumbar microdiscectomy. Spine J. 2010;10-7:575-80. http:// dx.doi.org/10.1016/j.spinee.2010.02.021

20. Kim Min Seok, Park Kun-Woo, Hwang Changju, Lee YoungKyun, Koo Ki Hyoung, Chang Bong-Soon, Lee Choon-Ki, Lee Dong-Ho. Recurrence rate of lumbar disc herniation after open discectomy in active young men. Spine. 2009; 34-1:24-9. http://dx.doi.org/10.1097/BRS.0b013e31818f9116

21. Thomé C, Barth M, Scharf J, Schmiedek P. Outcome after lumbar sequestrectomy compared with microdiscectomy: a prospective randomized study. J Neurosurg Spine. 2005;2-3: 271-8. http://dx.doi.org/10.3171/spi.2005.2.3.0271 
22. Vukas D, Ledić D, Grahovac G, Kolić Z, Rotim K, Vilendečić M. Clinical outcomes in patients after lumbar fisk surgery with annular reinforcement device: two-year follow up. Acta Clin Croat.2013;52-1:87-91.

23. Kim, Chi Heon; Chung, Chun Kee; Park, ChoonSeon; Choi, Boram; Kim, Min Jung; Park, ByungJoo. Reoperation rate after surgery for lumbar herniated intervertebral disc disease: $\mathrm{Na}^{-}$ tionwide Cohort Study. Spine. 2013;38-7:581-90. http:// dx.doi.org/10.1097/BRS.0b013e318274f9a7

24. Tureyen K. One-levelone-sided lumbar disc surgery with and without microscopic assistance: 1-year outcome in 114 consecutive patients. JNeurosurg, 2003;99:247-50.

25. Veresciagina K, Spakauskas B, Vytautas Ambrozaitis K. Clinical outcomes of patients with lumbar disc herniation, selected for one-level open-discectomy and microdiscectomy. Eur Spine
J. 2010;19-9:1450-8. http://dx.doi.org/10.1007/s00586-0101431-9

26. Porchet F, Bartanusz V, Kleinstueck FS, Lattig F, Jeszenszky D, Grob D, Mannion AF. Microdiscectomy compared with standard discectomy: an old problem revisited with new outcome measures within the framework of a spine surgical registry. Eur Spine J. 2009;18(Suppl3):S360-6. http://dx.doi.org/10.1007/ s00586-009-0917-9

27. Kahanovitz N, Viola K, Muculloch J. Limited surgical discectomy and microdiscectomy: a clinical comparison. Spine. 1989; 14-1:79-81.

28. Wolfhard C, Campbell B, Barbier D, Kretschmmer R, Yechiel $\mathrm{G}$. The Caspar microsurgical discectomy and comparison with a conventional standard lumbar disc procedure. Neurosurgery. 1991;28-1:78-86.

Sažetak

\section{STANDARDNA LUMBALNA DISKEKTOMIJA NASUPROT MIKRODISKEKTOMIJI - RAZLIKE U ISHODU LIJEČENJA I STOPI REOPERACIJE}

\section{Kovačević, N. Jovanović, M. Miletić-Kovačević, R. Nikolic, M. Peulic, K. Rotim, T. Sajko i L. Rasulić}

Mikrodiskektomija (MD) je danas prihvaćena kao operativna metoda izbora u liječenju lumbalne diskus hernije, ali se neurokirurzi nerijetko odlučuju za standardnu diskektomiju (SD) koja ne podrazumijeva upotrebu operativnog mikroskopa. U našoj studiji smo nastojali uočiti razlike vezano za rekurentnu diskus herniju i funkcionalni ishod kirurškog liječenja lumbalne diskus hernije uz uporabu operativnog mikroskopa i bez nje. Naša studija je uključila 167 bolesnika koji su podvrgnuti operaciji lumbalne diskus hernije tijekom trogodišnjeg razdoblja $(S D, n=111$ i $M D, n=56)$. Ishod liječenja procjenjivao se pomoću upitnika koji su bolesnici ispunjavali u tri vremenske točke. Vrijeme trajanja operacije, dužina hospitalizacije i reoperacije su također bilježeni. Nakon godinu dana praćenja prema našim rezultatima nije bilo statistički značajne razlike između skupina SD i MD u funkcionalnom ishodu liječenja, ali je zabilježena statistički značajna razlika u smanjenju boli u nozi u korist skupine MD. Prema učestalosti reoperacija s prosječnim razdobljem praćenja od 33,4 mjeseca, utvrđena je statistički značajna razlika u korist skupine $\mathrm{MD}$ (SD, 6,3\% i MD, 3,2\%). Nijednoj operativnoj tehnici ne može se dati prednost u smislu funkcionalnog ishoda liječenja, jer obje daju odlične rezultate. Ipak, naš izbor je mikrodiskektomija zbog niže stope rekurentne diskus hernije i višeg stupnja smanjenja boli u nozi.

Ključne riječi: Mikrodiskektomija; Standardna diskektomija; Ishod liječenja; Reoperacija 